\title{
Sports Spectators' Suspense: Affect and Uncertainty in Sports Entertainment
}

\author{
Silvia Knobloch-Westerwick ${ }^{1}$, Prabu David¹, Matthew S. Eastin², \\ Ron Tamborini ${ }^{3}$, \& Dara Greenwood ${ }^{4}$ \\ 1 School of Communication, The Ohio State University, Columbus, OH 43210, USA \\ 2 Department of Advertising, The University of Texas at Austin, Austin, TX 78712, USA \\ 3 Department of Communication, Michigan State University, East Lansing, MI 48824-1212 USA \\ 4 Department of Communication Studies, University of Michigan, Ann Arbor, MI 48104 USA
}

\begin{abstract}
To explain the attraction to sports in the media, suspense theory is extended to predict suspense during sports exposure. Viewers $(\mathrm{n}=113)$ of a college football game in an intense rivalry context reported their responses to the game during commercial breaks. Multilevel analysis of the longitudinal data shows that shifts in both positive and negative affect influence suspense of supporters of both teams. Likewise, affective dispositions (rooting for a team) emerge as precondition for greater suspense, regardless of specific team preference, even though habitual fan commitment did not affect suspense. Predictions regarding increased suspense due to lower certainty of the favored team's victory and due to smaller score difference were only corroborated for supporters of the winning team.
\end{abstract}

doi:10.1111/j.1460-2466.2009.01456.x

Sports events have a very long tradition of entertaining large audiences, as in the Olympic Games in ancient Greece or gladiator shows in ancient Rome. Nowadays, thanks to the mass media, modern sports events attract audiences of record-setting size. For example, Super Bowl football matches have been attended by more than 140 million viewers in the United States (Associated Press, 2006). This draw of sports and sports entertainment has been addressed in a few theoretical models by communication scholars and there has been some limited empirical examination of this topic (Bryant \& Raney, 2000; Raney, 2003). The current contribution aims to extend insight into sports spectators' experience of suspense through shifts in affect and uncertainty that are integral to a game.

Suspense has been identified as a key factor in the attraction to sports (as summarized by Bryant \& Raney, 2000). In addition, viewers' affective disposition toward the contestants, the conflict and drama inherent in the spectacle, augmented

Corresponding author: Silvia Knobloch-Westerwick; e-mail:knobloch-westerwick.1@osu.edu 
by formal presentation features, the favorableness of the outcome from the viewers' perspective, and the quality of play, also contribute to the entertainment experience of sports (Bryant \& Raney, 2000). These elements of sports entertainment are all very much intertwined with the phenomenon of suspense. We examined this interconnection by observing the experiences of audience members during an intense college football rivalry game between The Ohio State University (OSU) and University of Michigan (UM). Audience responses were collected in real time and in natural television viewing conditions. During each commercial break, supporters of OSU and UM filled out a short questionnaire, which included situational assessments of positive and negative affect, certainty of victory for their team, and suspense. The longitudinal data were analyzed using multilevel models.

\section{Ingredients of suspense}

Suspense is usually associated with fiction such as thriller and action movies. However, it can also arise in response to nonscripted portrayals, namely sports and news (Knobloch, Patzig, Mende, \& Hastall, 2004; Knobloch-Westerwick \& Keplinger, 2007). We refer to suspense as an audience experience-not a characteristic of the media message or plot. To characterize the experiential aspects, we turn to Zillmann's concise definition of suspense as "a noxious affective reaction that characteristically derives from the respondents' acute, fearful apprehension about deplorable events that threaten liked protagonists, this apprehension being mediated by high but not complete subjective certainty about the occurrence of the anticipated deplorable events" (Zillmann, 1996, p. 208). It is important to highlight three concepts that are central to this definition. First, noxious or negative affective reactions are stressed over positive reactions. Second, the liking of protagonists is crucial for rendering importance to the witnessed events. Third, high subjective certainty of deplorable events is emphasized.

\section{Positive and negative affect}

In general, the relationship between positive and negative affect in suspense experiences is an interesting one. First, the tension between the negative affect of fear that a deplorable outcome will materialize and the positive affect of hope for a happy ending is at the heart of the suspense phenomenon. This conflict between likelihood and preference creates suspense (Carroll, 1996). However, this is not to say that any combination of positive and negative affect represents or even only relates to the experience of suspense-for instance, Tellegen (1985) showed that low positive affect and high negative affect are distinguishing features of depression and anxiety. In other words, suspense levels cannot be equated merely to a constellation of affect because it involves additional aspects such as anticipations and being a witness rather than an actor (Zillmann, 1996). Second, it is intriguing that the typical suspense plot dedicates ample time to instilling negative emotions by showing liked 
protagonists in peril while the happy ending is comparatively brief. Yet viewers appear to enjoy suspense plots greatly overall. Zillmann (1996) explained this as the result of residual arousal from negative emotions, which amplifies the experience of positive emotions at the happy ending. Because negative affect tends to produce greater arousal than positive affect, it is an important dramaturgic tool for intense entertainment experiences. Given that physiological arousal decays fairly slowly, it lingers on as the cognitive representation of viewers adapts to the happy ending. These two components combined, according to Zillmann (1996), dictate the extent to which a happy ending is enjoyed: The intensity results from lingering arousal; the cognitive processing determines the valence of the experience. Similar processes, however, occur throughout exposure to the plot, resulting in shifts of negative and positive affect and "episodic suspense" (Zillmann, 1996). In short, the interplay of positive and negative affect is crucial for suspense as entertainment experience.

\section{Affective dispositions}

These important affective reactions result from empathizing with liked and disliked characters (Zillmann, 1996). The depiction of conflict of characters or forces is a key precondition for suspense-in fiction, this is typically the battle of the hero aiming to save the world from the villain. Sport competitions and matches most obviously portray rivaling individuals or teams who combat for victory, often exploiting all their physical and emotional resources, thus creating a clear-cut conflict that qualifies for great drama. The conflict is furthermore often emphasized through sports commentary, which enhances appreciation (Bryant, Brown, Comisky, \& Zillmann, 1982; Bryant, Comisky, \& Zillmann, 1977; Comisky, Bryant, \& Zillmann, 1977; Sullivan, 1991).

In well-designed fictional expositions, affective dispositions toward the conflicting parties are established through character development and plot. In contrast to movies, sports events do not feature character development and plot, even though sports coverage certainly provides a lot of "background" information about players and athletes that contributes to liking and disliking of characters in the sportscast. However, a positive affective disposition among sports viewers has been shown to result from geographic closeness, same nationality, or matched ethinicity between viewer and players (Owens \& Bryant, 1998; Sapolsky, 1980; Zillmann, Bryant, \& Sapolsky, 1989). Even though many sports viewers will hold stable dispositions toward teams, situational factors will play into rooting for players as well. For example, a sports viewer may usually root for his/her alma mater's team and dislike its key conference rival; however, if the rival team plays against a team from a distant location in the national championship, this viewer may prefer a victory of the team with geographic closeness. Hence, affective dispositions toward sports teams should depend in part on the constellation of factors surrounding the current game. These affective dispositions result in empathic responses to developments in the sports event with regard to the preferred team, for example, jubilance when the team 
scores. On the other hand, scores of the disliked team produce disenchantment due to counterempathy in which emotions opposite to those of the disliked players are experienced.

For many sports viewers, habitual fandom fuels affective dispositions and is often quite intense (e.g., Hartmann, Stuke, \& Daschmann, 2008). Indeed, research has shown that watching a favorite sports team win or lose has substantial influence on spectators' state self-esteem in the contexts of motor skills, mental skills, and dating success - positive in case of victory and negative in case of failure - that are just as large as for personal success or failure (Hirt, Zillmann, Erickson, \& Kennedy, 1992). In fact, many sports fans root so intensely for a team that they express this through logo displays on t-shirts, flags, car stickers and the like (Cialdini et al., 1976). In our empirical study, we will consider both situational affective disposition in the sense of rooting for a team and habitual fandom as factors for suspense.

\section{Certainty of negative outcome}

Suspense is said to arise from the uncertainty regarding which side will succeed in the end, yet maximum uncertainty does not produce maximum suspense (Comisky \& Bryant, 1982). Instead, suspense increases as onlooker's certainty that the feared outcome will materialize increases, stopping just short of total certainty. Once the spectator is fully certain that the feared loss of the game will occur, suspense abruptly ends and is replaced by disappointment. Research into connections between uncertainty and suspense has repeatedly corroborated that greater perceived likelihood of negative outcomes increases suspense (Comisky \& Bryant, 1982; KnoblochWesterwick \& Keplinger, 2007; Vorderer, 1994). In line with this pattern, research on reactions to sports programming (Gan, Tuggle, Mitrook, Coussement, \& Zillmann, 1997) has revealed that suspense corresponds to the closeness of a game such that smaller score differentials produce more suspense and subsequently more enjoyment (with the exception that, in contrast to men, women reported lower enjoyment of nail-biting maximum suspense).

Given that levels of certainty regarding a negative outcome are crucial for suspense, the amount of time that is left to "turn the tide" obviously plays an important role, too. The less time a liked team or a protagonist has to overcome the challenges, the higher suspense should be. This pattern has indeed been demonstrated for movie viewers' suspense ratings across time (Vorderer, Knobloch, \& Schramm, 2001) and, obviously, ticking time bombs are frequently used in many suspense movies. ${ }^{1}$ There are interesting parallels to sports programs that often display the remaining game time, which may also contribute to the suspense experience. However, sports vary greatly in that some games involve a preset play time (e.g., football), others last until a winner is determined (e.g., tennis), and some sports competitions are all about who achieves a goal first (e.g., marathon). The current study examines a football game, which will typically last about 3 hours - a length that encourages peripheral viewing initially and more focused attendance as the game progresses. 
Overall, sports viewing can be considered a risky entertainment choice in that this genre does not present meticulously scripted plots (professional wrestling may be an exception that illustrates where the line becomes blurry). Unlike the carefully designed plots in fictional drama, the timing of events in sports (touchdowns, scores, or injuries constitute crucial "events" in the sports context) is less predictable. Nonetheless, situational and cumulative effects of these experiences produce emotional states of hope and fear that are ultimately experienced as suspense. For example, if one team dominates throughout the game, little suspense will arise. Moreover, again in contrast to the typical fictional suspense plot, spectators' beloved teams can lose a game, possibly even undeservingly so, whereas the fictional hero in drama is bound to succeed in the end (unless the drama turns out to be a tragedy; Zillmann, 1996). While watching fiction, viewers do not keep that certainty of success in mind, but instead empathize with the characters and thus experience the fluctuations in uncertainty that ultimately produce suspense. While following sports, on the other hand, failure is a realistic possibility, which might further fuel the arousal and subsequently suspense. Hence, one can think of sports viewing as a risky entertainment selection, because satisfaction is certainly not guaranteed but could be more intense if the desired victory is achieved.

\section{Current research}

The current study examines how the interplay of positive and negative affect, affective dispositions, and subjective outcome certainty of sports viewers affect their suspense experience. In contrast to earlier research, sports viewers reported their continuous experience in natural viewing settings by completing online questionnaires during commercial breaks within a college football game between two rivals. Among football fans, this game had great significance because the stakes were quite high. One team, OSU, was playing for a berth in the national championship game and was favored to win because of home field advantage and their top national ranking. However, to reach the championship game, OSU had to beat their arch rival, the UM, which was the second-ranked team. Affective dispositions among fans of both teams are steadfast and intense because of the numerous occasions on which these teams have thwarted one another's chances of conference and national championships. In light of the excitement surrounding the game, it seemed appropriate to examine suspense. As we had hoped for, the game turned out to be a classic with a lot of scoring capped off by a dramatic finish.

Based on logic from the theorizing on suspense summarized in the previous sections, we hypothesized the following.

H1: Shifts in positive affect while watching a sports game increase suspense.

H2: Shifts in negative affect while watching a sports game increase suspense.

H3: Suspense while watching a sports game is more intense among viewers with more positive affective dispositions toward one team, compared to viewers without a preference. 
H4: Suspense while watching a sports game is more intense among viewers who report higher team commitment regardless of preferred team.

H5: Suspense while watching a sports game is more intense if the certainty that the preferred team will lose the game increases (short of total certainty about failure).

H6: The smaller the difference in score (or, the tighter the game), the more suspense is experienced by viewers.

\section{Method}

\section{Participants and design}

Participants were recruited from introductory courses in communication from three universities in the Midwestern United States. Out of the 113 participants, 65 (57.5\%) were from Michigan State University, 40 (35.4\%) from OSU, and 8 (7.1\%) from UM. About one-half of the participants (49.6\%) were OSU supporters, $30.1 \%$ were UM supporters, and the rest $(20.4 \%)$ said they did not care who won the game. Females $(61.1 \%)$ outnumbered males $(38.9 \%)$ and the average age of participants was 21 $(S D=2.2)$. Three out of four $(77.9 \%)$ participants watched the game with friends, while the others watched the game alone. The last two variables, gender (see Gan et al., 1997; Gantz \& Wenner, 1991; Sargent, Zillmann, \& Weaver, 1998) and whether the game was watched alone (Hocking, 1982), were employed as control variables.

\section{Procedure}

Ecological momentary assessments (EMA) were collected at every commercial break during the 2006 OSU-Michigan football game, which was played at OSU. Before kickoff, participants logged into a website and filled out questions on demographics, fan commitment, and whether they were watching the game alone or with friends. Immediately after completing these questions, they were directed to another webpage with the EMA items. These items focused on three components: likelihood estimates of who will win the game, assessments about the game itself, including how suspenseful and thrilling the game was at the moment, and participants' situational affect states. The EMA page was open only during commercial breaks and participants were asked to fill out a brief assessment at every break. The availability of the EMA was restricted to commercial breaks to ensure that the situational assessments were captured in the moment as "hot" emotions. All assessment items were presented as radio buttons, and most students completed the EMA questionnaire in less than a minute. Compliance with EMA was quite high. Out of the 24 measurement episodes, on average participants completed $22.2(S D=1.8)$ episodes. Finally, at the end of the game, a posttest was administered, in which many of the items that were first presented before the game were repeated. 


\section{Measures}

Affective disposition

In the pregame questionnaire, participants were asked "Which team are you rooting for in this game? OSU/UM/Don't care." This question served to establish whether a participant held a positive affective disposition toward a team or not and which team was preferred.

\section{Sports spectator identification scale}

The sports spectator identification scale (SSIS) was used to assess participant's fan commitment with regard to his or her favorite team (Wann \& Brascombe, 1993). A 7-point scale ( $1=$ strongly disagree, $7=$ strongly agree $)$ was used to rate the seven items, which were averaged to compute a fan commitment score $(M=4.7$, $S D=1.9$ ), with Cronbach's $\alpha=0.96$. Sample items included, "I am a committed fan of my team," and "I have been a fan of my team since I began watching college football." Before answering the items on this scale, participants were asked to base their fan commitment responses on the team they were rooting for in the game. Those who said that they "didn't care" were given the option of choosing their favorite college team and associating their responses with this team. In light of the fact that the MSU students constituted more than one-half of the study participants and that many of these students were fans of neither team, the option of choosing a different team than OSU or UM was necessary. The SSIS was presented about 15 minutes before the first EMA assessment.

\section{Likelihood of OSU win}

Subjective certainty was operationally defined as likelihood. The likelihood item was an 11-point, bipolar scale with the two anchors defined as $100 \%$ likely that UM will win and $100 \%$ likely that OSU will win. The midpoint was defined as 50-50 chance for both teams. From the midpoint, the likelihood estimates were incremented by units of 10 in either direction. Hence the likelihood of an OSU win increased from 50 to $100 \%$ in five steps from the midpoint to the right anchor. Similarly, the likelihood of a Michigan win increased in five steps from the midpoint to the left anchor. Participants provided likelihood estimates at each measurement episode. These estimates were recoded to create a measure from 0 to 10 , in which 0 equaled $0 \%$ likelihood of OSU win and 10 equaled $100 \%$ chance of an OSU win. If a UM fan indicated $60 \%$ chance of a UM win, it was converted to $40 \%$ likelihood of OSU win. The recoding of certainty made data interpretation easier and the assessments were anchored to OSU, the winning team.

\section{Situational suspense}

Situational suspense was measured as an average of suspense and thrilling, which were correlated, $r(2490)=0.89, p<.001$. Suspense and thrilling were rated on a 7-point scale $(1=$ not at all, $7=$ very $m u c h)$ in response to the following two questions: At this point, do you find the game suspenseful? At this point, do you find the game thrilling? Both items were assessed at each measurement episode. Given that 
participants responded to situational questions multiple times during the game, we then limited assessments to these two items in order to keep interruptions during TV viewing to a minimum. ${ }^{2}$

\section{Positive and negative affect}

Four items from the PANAS scale (Watson, Clark, \& Tellegen, 1988), alert, excited, happy, and joyful, were administered at every commercial break to assess positive affect, which were rated on a 7 -point scale $(1=$ not at all, $7=$ very much $)$. The positive affect items were strongly correlated with a reliability of $\alpha=0.91$. Along with the positive items, four negative affect items, upset, frustrated, nervous, and angry, also were presented, which had equally strong internal reliability, $\alpha=.90$.

\section{Score difference}

The difference in score between OSU and UM was calculated before each commercial break and used as an indicator of closeness of the game.

\section{Results}

The data were arranged in person-interval form, with a maximum of 24 rows of data for each individual, with each row accounting for a measurement episode that occurred during a commercial break. Person-level variables, such as gender and team support were repeated for all rows of data for a participant.

After a visual analysis of the data and an examination of score differences, it appeared that suspense was higher during the second half of the game than during the first half. This converges with our considerations above on the relevance of time for suspense and viewing sports. Further, suspense spiked on different occasions during the second half when Michigan staged a comeback, in part capitalizing on OSU's mistakes, setting up a thrilling finish. Hence we decided to focus only on the 10 measurement episodes from the second half, when the game was close as evidenced by the smaller difference in scores. Positive and negative affect, suspense, confidence in an OSU win, and points are presented in Figure 1. While positive affect and the likelihood of an OSU win seemed to move in tandem among OSU supporters, the two seemed to diverge among UM fans. In addition, it appeared that those who did not support one of the teams in the contest showed less emotional movement over the course of the game. Given the focus on suspense, only the data for those who supported one of the two teams were retained for further analysis.

As a preliminary analysis, the grand means of SSIS, suspense, likelihood, and affect were examined (see Table 1). Grand means were obtained by averaging individual means over time and subsequently averaging across individuals. Fan commitment was significantly higher $(p<.05)$ among OSU supporters $(M=5.3, S D=1.8)$ than among UM supporters $(M=4.1, S D=2.0)$. By the same token, the difference between OSU supporters and those who did not care who won $(M=4.2, S D=1.7)$ also was significant. These differences in fandom can be explained in part because 

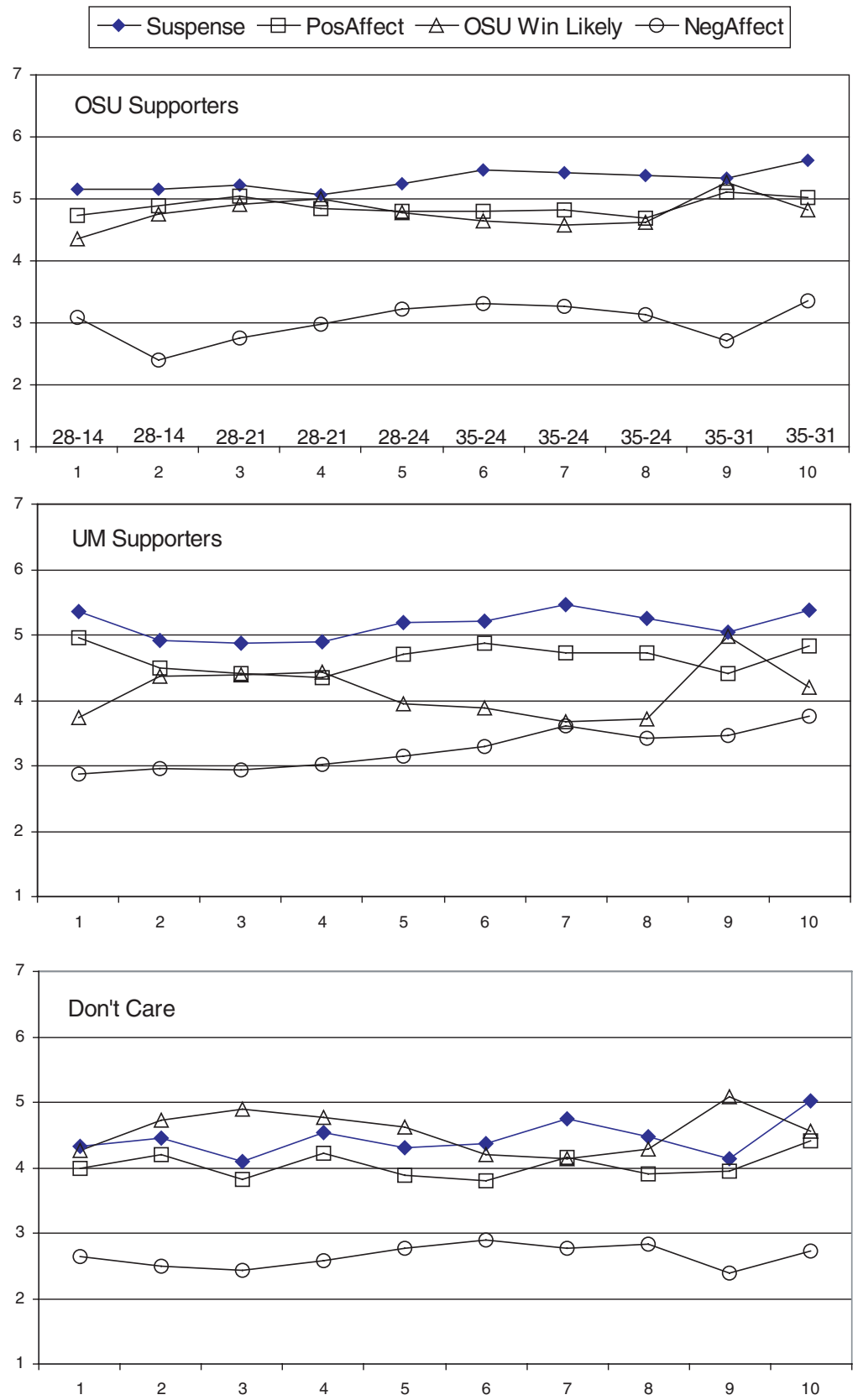

Figure 1 Audience ratings of suspense, positive affect, negative affect, and certainty of OSU win. Certainty of OSU win, which was measured on a $0-100 \%$ scale is shown on a 7-point scale for ease of display. Only the data from the second half of the game are shown, when OSU led UM 28-14. $x$-axis labels denote commercial breaks during the second half of the OSU-Michigan game when the EMA was collected. The OSU-UM score at each commercial break is shown above the $x$-axis in the top panel. 
Table 1 Summary Statistics, $M(S D)$, by Team Support for Key Variables

\begin{tabular}{lccc}
\hline & OSU & UM & Don't Care \\
& Supporters & Supporters & \\
& $N=56$ & $N=23$ & $N=34$ \\
\hline SSIS & $5.3^{a}$ & $4.1^{b}$ & $4.2^{b}$ \\
Likelihood of OSU win & $(1.8)$ & $(2.0)$ & $(1.7)$ \\
& $75.0 \%$ & $64.7 \%$ & $71.4 \%$ \\
Positive affect & $(20.3)$ & $(24.1)$ & $(21.6)$ \\
& $4.9^{a}$ & 4.7 & $4.0^{b}$ \\
Negative affect & $(1.6)$ & $(1.6)$ & $(1.9)$ \\
& 3.1 & 3.3 & 2.7 \\
Suspense & $(1.8)$ & $(1.7)$ & $(1.7)$ \\
& $5.3^{a}$ & 5.2 & $4.4^{b}$ \\
& $(1.7)$ & $(1.9)$ & $(2.0)$ \\
\hline
\end{tabular}

Note: OSU, The Ohio State University; UM, University of Michigan; SSIS, Sports Spectator Identification Scale. Positive and negative affect, as well as suspense were measured on a 7-point scale; greater number indicates higher emotion. For the SSIS measure, those who said that they "didn't care" were given the option of choosing their favorite college team and connecting with this team. The subscripts "a" and "b"denote difference significant at $p<.05$; effect tested using fixed effect contrast in the multilevel model.

most of the UM supporters were MSU students. Though they were rooting for their in-state team, they were less likely to be intensely committed fans in comparison to OSU supporters, who were rooting for their own team to beat its archrival en route to a berth in the national championship game.

The likelihood of an OSU win averaged over the course of the game was 75.0\% $(S D=20.3)$ among OSU supporters and 64.7\% $(S D=24.1)$ among Michigan supporters. Among nonpartisans, the average likelihood of an OSU win was $71.4 \%$ $(S D=21.6)$. For positive affect, there was no difference between OSU $(M=4.9$, $S D=1.6)$ and $\mathrm{UM}(M=4.7, S D=1.6)$, though the affect reported by those who did not care was lower $(M=4.0, S D=1.9)$ than OSU supporters at $p<.05$. Negative affect followed the same pattern, with no difference between OSU $(M=3.1$, $S D=1.8)$ and $U M(M=3.3, S D=1.7)$, but with lower ratings among those who said they did not care $(M=2.7, S D=1.7)$, which was not statistically significant.

On a 7-point scale, in which 7 represented a high level of suspense, there was no difference in average suspense between OSU supporters $(M=5.3, S D=1.7)$ and Michigan supporters $(M=5.2, S D=1.9)$, indicative of the closeness of the game. However, among those who said they did not care who won the game, average suspense was lower $(M=4.4, S D=2.0)$ than among supporters of OSU; the difference for the comparison with UM supporters fell just short of significance $(p<.10)$. This corroborates H3. 
After examining the summary statistics and time series plots, the focus shifted to longitudinal, multilevel analysis of suspense. The data analysis strategy pursued in this paper is drawn from standard texts and tutorials that offer guidelines for withinindividual longitudinal analysis (e.g., Hox, 2002; Peugh \& Enders, 2005; Raudenbush \& Bryk, 2002; Singer, 1998).

\section{Multilevel models}

In Equation 1a, a Level 1 model, suspense is written as a function of each individual's average suspense and each individual's residuals from individual mean at each time point. In Equation 1b, each individual's mean from Equation 1a is further modeled as a deviation from the grand mean, $\beta_{00}$, and random error $\mathrm{u}_{0 i}$. Note that suspense is double subscripted to account for an observation at measurement episode $t$ by participant $i$. The unconditional model was evaluated by substituting Equation $1 \mathrm{~b}$ into 1 a.

$$
\begin{aligned}
\operatorname{Susp}_{i t} & =\pi_{0 i}+\mathrm{e}_{i t} \\
\pi_{0 i} & =\beta_{00}+\mathrm{u}_{0 i}
\end{aligned}
$$

In the next step, Equation $1 \mathrm{a}$ and $1 \mathrm{~b}$ were rewritten to include the explanatory variables that were derived from suspense theory. As mentioned before, gender (see Gan et al., 1997; Gantz \& Wenner, 1991; Sargent, Zillmann, \& Weaver, 1998) and whether the game was watched alone (Hocking, 1982) served as control variables.

$$
\begin{aligned}
& \operatorname{Susp}_{i t}=\pi_{0 i}+\pi_{1 i} \operatorname{Susp}_{i t-1}+\pi_{2 i} \text { ScoreDiff }_{t}+\pi_{3 i} \text { Likely }_{i t}+\pi_{4 i} \operatorname{SPA}_{i t} \\
& +\pi_{5 i} \mathrm{SNA}_{i t}+\mathrm{e}_{i t} \\
& \pi_{0 i}=\beta_{00}+\beta_{01} \text { Gender }_{i}+\beta_{02} \text { Alone }_{i}+\beta_{03} \text { SSIS }_{i}+\beta_{04}{\overline{\text { Likely }_{i}}}+\beta_{05}{\overline{\mathrm{PA}_{i}}}_{i} \\
& +\beta_{06} \overline{\mathrm{NA}}_{i}+\mathrm{u}_{0 i} \\
& \pi_{3 i}=\beta_{30}+\beta_{31} \overline{\text { Likely }}_{i}+\mathrm{u}_{3 i}
\end{aligned}
$$

In Equation 2a, a Level 1 model, ScoreDiff $t$ is the difference in points between the two teams at every commercial break, Likely ${ }_{i t}$ is the situational likelihood assessment of an OSU victory and $\mathrm{SPA}_{i t}$ and $\mathrm{SNA}_{i t}$ are situational positive affect and situational negative affect assessments at each measurement episode by each participant.

In Equation $2 \mathrm{~b}$, a Level 2 model, the intercept $\pi_{0 i}$ from Equation $2 \mathrm{a}$ is written as a function of individual difference variables, Gender $r_{i}$, watching the game alone or with friends $\left(\right.$ Alone $\left._{i}\right)$, and sports spectator identification scale $\left(\mathrm{SSIS}_{i}\right) . \overline{\text { Likely }}_{i}, \overline{\mathrm{PA}}_{i}$, and $\overline{\mathrm{NA}}_{i}$ are individual averages of the situational assessments of likelihood, positive affect, and negative affect from Equation 2a. Individual averages were introduced because it is a recommended practice to use the averages of situational shifts as covariates in the Level 2 model when examining individual shifts over time in the Level 1 model (David, Horton, \& German, 2008; Theiss \& Solomon, 2006). 
Equation $2 \mathrm{c}$ provides for an examination of certainty both as situational likelihood and as an interaction between average likelihood and situational likelihood. If Equation $2 c$ is substituted for $\pi_{3 i}$ in Equation $2 a$, the main effect for situational likelihood $\left(\right.$ Likely $\left._{i t}\right)$ and the interaction Average $\times$ Situational Likelihood $\left(\overline{\operatorname{Likely}}_{i} \times\right.$ Likely $_{i t}$ ) can be examined.

Before presenting the parameter estimates, which were estimated using the mixed procedure in SPSS 14.0, a couple of other aspects of the data analysis deserve elaboration. Fist, all continuous variables in the Level 1 model were individual mean centered and all continuous variables in the Level 2 models were grand mean centered. Both types of centering, or differencing from means, are strongly recommended in multilevel analysis and allow for easier interpretation of data (Singer, 1998). Second, it deserves mention that $\mathrm{u}_{0 i}$ and $\mathrm{u}_{3 i}$ are random error terms, which are different from the residual error, $\mathrm{e}_{i t}$. A detailed discussion of the difference between the two errors is beyond the scope of this paper. However, it is worth noting that the $u$ terms represent the unexplained between-individual variance and the e term represents the unexplained within-individual variance. In the next step of the analysis, the variance was partitioned and the ratio between the between- and within-individual variance examined separately for OSU and UM supporters after excluding participants who said they did not care who won the game. The parameter estimates from these models are presented in separate columns in Table 2.

\section{Suspense among OSU supporters}

The unconditional model provides an assessment of explainable variance in suspense, which can be decomposed as between- and within-individual variances. The intercept or between-individual variance coefficient $(2.42, S E=.47)$ was greater than the residual or within-individual coefficient $(.42, S E=.03)$. The intraclass coefficient (ICC), which is the ratio of the within-individual variance and the sum of the between- and within-individual variances $[.42 /(2.42+.42)]$, provides an index of the amount of variance within individuals. It appears that for OSU supporters $15 \%$ of the variance was within individuals, whereas $85 \%$ of the variance in suspense in the second half of the OSU-Michigan game can be attributed to between-individual differences. In the following steps, the explainable variance in suspense was examined by introducing explanatory variables from the literature.

The addition of the explanatory variables improved the model fit with a change in the deviance statistic, $\chi^{2}=241, d f=14, p<.001$. Given the longitudinal nature of the data, lagged suspense was introduced to partial out autocorrelations before the effects of other variables were examined. A key finding was the role of affect on suspense. Both average positive affect $(.70, S E=.09)$ and situational shifts in positive affect $(.41, S E=.04)$ emerged as significant predictors. Although the average negative affect was not significant, situational negative affect emerged with a positive coefficient $(.21, S E=.03)$. In other words, situations that engendered affect, both positive and negative, contributed to increased suspense. These results support $\mathrm{H} 1$ and $\mathrm{H} 2$. 
Table 2 Predicting Suspense from Between-Individual and Within-Individual Situational Differences by Team Support

\begin{tabular}{|c|c|c|}
\hline & OSU Supporters & UM Supporters \\
\hline \multicolumn{3}{|l|}{ Between-individual } \\
\hline Intercept & $4.40(.30)^{* * *}$ & $4.48(.38)^{* * *}$ \\
\hline Gender & $-.14(.20)$ & $.45(.31)$ \\
\hline Watching alone & $-.24(.23)$ & $.00(.31)$ \\
\hline Fan commitment & $.05(.06)$ & $.04(.07)$ \\
\hline Avg. likely (OSU win) & $-.14(.06)^{*}$ & $-.08(.06)$ \\
\hline Avg. positive affect & $.70(.09)^{* * *}$ & $.98(.11)^{* * *}$ \\
\hline Avg. negative affect & $.07(.07)$ & $.15(.11)$ \\
\hline \multicolumn{3}{|l|}{ Within-individual situational } \\
\hline Suspense $\operatorname{lag}_{1}$ & $.22(.04)^{* * *}$ & $.08(.04)$ \\
\hline Score difference & $-.02(.01)^{* *}$ & $.01(.01)$ \\
\hline Sit. certainty (OSU win) & $.12(.07)$ & $-.07(.07)$ \\
\hline Avg. $\times$ Sit. likely & $.00(.01)$ & $-.03(.02)^{*}$ \\
\hline Sit. positive affect & $.41(.04)^{* * *}$ & $.67(.04)^{* * *}$ \\
\hline Sit. negative affect & $.21(.03)^{* * *}$ & $.22(.03)^{* * *}$ \\
\hline \multicolumn{3}{|l|}{ Variance components } \\
\hline Intercept & $.39(.10)^{* * *}$ & $.45(.13)^{* * *}$ \\
\hline Residuals & $.29(.02)^{* * *}$ & $.33(.03)^{* * *}$ \\
\hline Sit. certainty & $.02(.01)$ & $.00(.00)$ \\
\hline \multicolumn{3}{|l|}{ Model fit } \\
\hline$-2 \mathrm{LL}$ & 986 & 652 \\
\hline$d f$ & 17 & 17 \\
\hline$-2 \mathrm{LL}$ change, $\chi^{2}(d f)^{\mathrm{a}}$ & $241(14)^{* * *}$ & $286(14)^{* * *}$ \\
\hline
\end{tabular}

Note: Estimates of coefficients (SE) presented in the columns. OSU, The Ohio State University; UM, University of Michigan; Avg., average of all assessments by an individual over time; Sit., situational assessment by an individual at one time. The superscript " $\mathrm{a}$ " indicates change in $-2 L L$ from unconditional model with only the intercept as fixed effect.

${ }^{* * *} p<.001{ }^{* *} p<.01{ }^{*} p<.05$.

Furthermore, a drop in average likelihood of an OSU win (or an increase in average likelihood of an OSU loss) led to an increase in suspense, which is evident from the negative coefficient $(-.14, S E=.06)$ for average likelihood of an OSU win. The finding provides support for $\mathrm{H} 5$ in which it was predicted that as the likelihood of a loss increases, suspense increases. Among OSU supporters, shifts in situational likelihood of win did not affect suspense. The absence of an effect of situational likelihood may be tied to loyalty and fan support, which is examined in the discussion. Finally, in support of H6, the closeness of the game, defined as the difference in score, was predictive of suspense. As the difference in points increased, suspense decreased $(-.02, S E=.01)$. 


\section{Suspense among Michigan supporters}

For UM supporters, the between-individual variance $(2.96, S E=.73)$ was greater than the residual or within-individual variance $(.73, S E=.06)$. These variance estimates were obtained from the unconditional model. The ICC $[.73 /(2.96+.73)]$ was computed and the ratio of within-individual variance to the total variance was $20 \%$.

Among UM supporters, the pattern of findings for affect was similar to the findings for OSU supporters. Both average $(.98, S E=.11)$ and situational (.67, $S E=.04)$ positive affect were significant predictors of suspense. Further, situational negative affect $(.22, S E=.03)$ was significant, but average negative affect was not. These results again support $\mathrm{H} 1$ and $\mathrm{H} 2$. In essence, the role of affect on suspense appears to be quite similar among supporters of both the winning and losing teams, despite the characteristics of the game in which OSU led throughout the game and UM had a realistic possibility of winning the game till the very end.

Average likelihood did not have an effect on suspense among UM supporters. Instead, an interaction between average and situational likelihood $(-.03, S E=.02)$ was significant. The negative sign of the interaction suggests that as likelihood of an OSU win increased, suspense decreased, only among those with a higher than average certainty that OSU would win. In short, although the effect of certainty of OSU win on suspense was less convincing among supporters of UM, the direction of the effect was the same for supporters of both the losing and the winning team.

\section{Discussion}

The current study built on suspense theorizing on fictional drama and extended it to the entertainment experience while watching sports. The empirical test of hypotheses derived from suspense theory employed longitudinal data gathered from participants in natural viewing situations during the course of a live college football game.

The multilevel model analysis yielded support for the two hypotheses about the importance of both positive and negative affect for suspense. Suspense increased with greater situational shifts for positive and negative affect. Although the influence of positive affect was greater, the effect of negative affect was substantial as well. Furthermore, this pattern emerged for both groups of football team supporters, regardless of seeing the preferred team leading or lagging behind. These findings are remarkable in that much scholarly writing discusses the importance of the plot for the emotional ups and downs of the onlooker (e.g., for an overview, see Vorderer \& Knobloch, 2000) but empirical evidence for the influence thereof defines a void. Traditional approaches of averaging over time as shown in Table 1 do not account for the subtle shifts in meaningful ways. By using continuous data from the entertainment experience and employing multilevel, longitudinal analysis some of these challenges were addressed. The current research design and analysis presents an encouraging approach to tackle these crucial issues of entertainment research further.

The prediction that holding an affective disposition for an involved party would foster suspense (H3) was supported, as participants who identified themselves as 
supporters of OSU experienced more suspense than those participants who did not root for a team. The same effect of affective disposition among UM supporters fell just short of significance, probably because their disposition was somewhat weaker, as they were mostly not students of UM (see limitations discussed below). However, suspense was not affected by intensity of fan commitment as measured by the SSIS scale. Evidently the habitual emotional connection with a team does not matter much for this entertainment phenomenon. This implies that concepts from entertainment theory and research into sport spectatorship deserve closer inspection and comparisons in future research.

Yet the fifth hypotheses that suspense would be more intense with greater certainty that the preferred team will lose (short of total certainty about failure) found only support among one group of supporters, namely those of the team that was generally considered the likely winner, which ultimately won the game. The finding of presence of a strong effect of certainty for OSU supporters and less clear effect for UM supporters may have been confounded by the differences in fan commitment. A majority of OSU supporters were rooting for their own school and showed significantly stronger fandom. UM supporters, on the other hand, exhibited a weaker habitual connection because many of them were from a different school, MSU, and were rooting for an in-state team, but without the same passion as they would for their alma mater.

As it stands, the role of certainty about outcomes for suspense is different in the sport context than in fictional entertainment. This difference may result from the closer affiliation of sports fans with their teams compared to connections between viewers and fictional characters. Reported estimates regarding the outcome may be biased among sport spectators who see their team lose a game. Some wishful thinking may be at work because winning and losing has implications for spectators' self-esteem (Hirt et al., 1992).

In conceptual terms, the current analysis employed affect as predictor for suspense. This approach implies that there is a causal relationship between general dimensions of affect and the more specific experience of suspense. An alternative interpretation of suspense definitions (discussed above) could imply that affect and suspense are identical; in other words, because suspense is an affective phenomenon (at least in part), it could be measured with general affect operationalizations. ${ }^{3}$ In that case, the analysis presented here would be using redundant measures to establish causality between two phenomena that could be viewed as two sides of the same coin. Yet we consider general affective states as conceptually distinct from suspense, especially given that this phenomenon requires certain cognitive components and that there are many very different affect constellations that the PANAS can measure as well (e.g., Tellegen, 1985). Moreover, the current analysis was interested in shifts in affect in particular and the corresponding shifts in suspense.

Some limitations of our research, however, deserve attention as well. The most intense fans of the participating teams were certainly less likely to participate in our study, as they probably wanted to focus on the event as such. Hence, our sample does not cover the full range of sports viewers. By the same token, it must be 
acknowledged that gathering data from respondents in natural viewing contexts still means that they fill out survey pages, which is an unavoidable interruption of the normal media use process. Finally, there was potential for some imbalance in fandom. While OSU supporters were typically students at OSU, most of the UM supporters were students at Michigan State University. Despite best recruitment efforts, few UM fans participated in the study. However, this imbalance was controlled for by the fan commitment measure, SSIS, and a categorical variable that controlled for the team an individual was rooting for.

Overall, the application of entertainment theory to sports viewing has proven to be very fruitful. Three hypotheses were supported, two found partial support-yet incorporating habitual sports fandom as a concept from sports research did not explain appreciable variance. Hence, future research along these lines should further our understanding of the draw of sports. Moreover, working with longitudinal data to represent processes during the entertainment viewing experience provided very valuable insight into the emotional rollercoaster that great entertainment is known for. This approach should help greatly in developing models for other entertainment genres that are less well understood than suspense, such as tragedy or mystery.

\section{Notes}

1 But even when the time dimension is not stressed in a movie plot, viewers may often take it into consideration as they often have an idea when a movie is scheduled to end. In many TV viewing settings, the screen may be located right above a VCR or cable receiver with a time display, and viewers know, for example, that the movie will end at the full hour.

2 To address a reviewer's concern that perceiving media content as suspenseful does not necessarily correspond with the viewer's emotional condition, we collected ratings from 81 students in an introductory communication class by showing them the opening scene from the movie Cliffhanger (1993) (accessible at YouTube.com) in which a mountain climber tries to save a woman's life after her harness broke and she is left dangling over a deep chasm in the Rocky Mountains. Participants responded to the questions "How much suspense did you experience while watching the movie segment?" and "How suspenseful was the movie segment?" on 11-point scales ranging from 0 to 10, with "No suspense at all" and "An extreme level of suspense" on the one hand and "No suspense at all" and "Extremely suspenseful" on the other hand. These two ratings were strongly correlated at $r=.72, p<.001$. Thus these two ways of assessing suspense, either by referring to the media content or to the experience, are sufficiently correlated to assume that they both represent suspense experiences.

3 As suggested per reviewer's comment.

\section{References}

Associated Press (2006, February 7). Super Bowl 2nd-most watched show ever. Retrieved July 15, 2007, from http://www.msnbc.msn.com/id/11205332/

Bryant, J., Brown, D., Comisky, P. W., \& Zillmann, D. (1982). Sports and spectators:

Commentary and appreciation. Journal of Communication, 32, 109-119. 
Bryant, J., Comisky, P., \& Zillmann, D. (1977). Drama in sports commentary. Journal of Communication, 27, 140-149.

Bryant, J., \& Raney, A. A. (2000). Sports on the screen. In D. Zillmann, \& P. Vorderer (Eds.), Media entertainment: The psychology of its appeal (pp. 153-174). Mahwah, NJ: Erlbaum.

Carroll, N. (1996). The paradox of suspense. In P. Vorderer, H. J. Wulff, \& M. Friedrichsen (Eds.), Suspense: Conceptualizations, theoretical analyses, and empirical explorations (pp. 71-92). Mahwah, NJ: Erlbaum.

Cialdini, R. B., Borden, R. J., Thorne, A., Walker, M. R., Freeman, S., \& Sloan, L. R. (1976). Basking in reflected glory: Three (football) field studies. Journal of Personality and Social Psychology, 34, 366-375.

Comisky, P., \& Bryant, J. (1982). Factors involved in generating suspense. Human Communication Research, 9, 49-58.

Comisky, P., Bryant, J., \& Zillmann, D. (1977). Commentary as substitute for action. Journal of Communication, 27, 150-153.

David, P., Horton, B., \& German, T. (2008). Dynamics of affect and entertainment in a Super Bowl audience: A multilevel approach. Communication Research, 35(3), 398-420.

Gan, S.-1., Tuggle, C. A., Mitrook, M. A., Coussement, S. H., \& Zillmann, D. (1997). The thrill of a close game: Who enjoys it and who doesn't? Journal of Sport and Social Issues, $21,53-64$.

Gantz, W., \& Wenner, L. A. (1991). Men, women, and sports: Audience experiences and effects. Journal of Broadcasting and Electronic Media, 35, 233-243.

Hartmann, T., Stuke, D., \& Daschmann, G. (2008). Positive parasocial relationships with drivers affect suspense in racing sport spectators. Journal of Media Psychology, 20(1), $24-34$.

Hirt, E. R., Zillmann, D., Erickson, G. A., \& Kennedy, C. (1992). Costs and benefits of allegiance: Changes in fans' self-ascribed competencies after team victory versus defeat. Journal of Personality and Social Psychology, 63, 724-738.

Hocking, J. E. (1982). Sports and spectators: Intra-audience effects. Journal of Communication, 32, 100-108.

Hox, J. J. (2002). Multilevel analysis: Techniques and applications. Mahwah, NJ: Erlbaum.

Knobloch, S., Patzig, G., Mende, A. -M., \& Hastall, M. (2004). "Affective News"-Effects of discourse structure in narratives on suspense, curiosity, and enjoyment while reading news and novels. Communication Research, 31, 259-287.

Knobloch-Westerwick, S., \& Keplinger, C. (2007). Thrilling news: Factors generating suspense during news exposure. Media Psychology, 9, 193-210.

Owens, J. W., \& Bryant, J. (1998, July). The effects of a hometown ("Homer") announcer and color commentator on audience perspectives and enjoyment of a sports contest. Paper presented at the annual meeting of the International Communication Association, Jerusalem, Israel.

Peugh, J. L., \& Enders, C. K. (2005). Using the SPSS mixed procedure to fit cross-sectional and longitudinal multilevel models. Educational and Psychological Measurement, 65(5), $1-25$.

Raney, A. A. (2003). Enjoyment of sports spectatorship. In J. Bryant, D. Roskos-Ewoldsen, \& J. Cantor (Eds.), Communication and emotion: Essays in honor of Dolf Zillmann (pp. 397-416). Mahwah, NJ: Erlbaum.

Raudenbush, S. W., \& Bryk, A. S. (2002). Hierarchical linear models: Applications and data analysis methods (2nd ed.). Thousand Oaks, CA: Sage. 
Sapolsky, B.S. (1980). The effect of spectator disposition and suspense on the enjoyment of sport contests. International Journal of Sport Psychology, 11, 1-10.

Sargent, S. L., Zillmann, D., \& Weaver, J. B., III. (1998). The gender gap in the enjoyment of televised sports. Journal of Sports and Social Issues, 21, 46-64.

Singer, J. D. (1998). Using SAS PROC MIXED to fit multilevel models, hierarchical models, and individual growth models. Journal of Educational and Behavioral Statistics, 24(4), $323-355$.

Sullivan, D. B. (1991). Commentary and viewer perception of player hostility: Adding punch to televised sport. Journal of Broadcasting and Electronic Media, 35, 487-504.

Tellegen, A. (1985). Structures of mood and personality and their relevance to assessing anxiety, with an emphasis on self-report. In A. H. Tuma, \& J. D. Maser (Eds.), Anxiety and the anxiety disorders (pp. 681-706). Hillsdale, NJ: Erlbaum.

Theiss, J. A., \& Solomon, D. H. (2006). Coupling longitudinal data and multilevel modeling to examine the antecedents and consequences of jealousy experiences in romantic relationships. Human Communication Research, 32(4), 469-503.

Vorderer, P. (1994). Was macht die Rezeption von Filmen spannend? [transl.: What makes the reception of movies suspenseful?]. Medienpsychologie: Zeitschrift fur Individual- \& Massenkommunikation, 6, 103-109.

Vorderer, P., \& Knobloch, S. (2000). Drama, suspense, and conflict. In D. Zillmann, \& P. Vorderer (Eds.), Media entertainment: The psychology of its appeal (pp. 59-72). Mahwah, NJ: Erlbaum.

Vorderer, P., Knobloch, S., \& Schramm, H. (2001). Does entertainment suffer from interactivity? The impact of watching an interactive TV movie on viewers' experience of entertainment. Media Psychology, 3(4), 343-363.

Wann, D., \& Branscombe, N. (1993). Sports fans: Measuring degree of identification with their team. International Journal of Sport Psychology, 24, 1-17.

Watson, D., Clark, L. A., \& Tellegen, A. (1988). Development and validation of brief measures of positive and negative affect: The PANAS scales. Journal of Personality and Social Psychology, 54, 1063-1070.

Zillmann, D. (1996). The psychology of suspense in dramatic exposition. In P. Vorderer, H. J. Wulff, \& M. Friedrichsen (Eds.), Suspense: Conceptualizations, theoretical analyses, and empirical explorations (pp. 199-231). Mahwah, NJ: Erlbaum.

Zillmann, D., Bryant, J., \& Sapolsky, B. S. (1989). Enjoyment from sports spectatorship. In J. H. Goldstein (Ed.), Sports, games, and play: Social and psychological viewpoints (2nd ed., pp. 241-278). Hillsdale, NJ: Erlbaum. 


\title{
体育观众的悬念 : 体育娱乐中的情感和不确定性
}

\author{
Silvia Knobloch-Westerwick \\ Prabu David \\ 俄亥俄州立大学 \\ Matt Eastin \\ 德克萨斯大学 \\ Ronald Tamborini \\ 密歇根州立大学 \\ Dara Greenwood \\ 密歇根大学
}

\section{【摘要 : 】}

为了解释媒体中体育的吸引力, 本文应用悬念理论来预测在观看体育时的悬念。在竞争激 烈的大学橄榄球比赛中, 观众 $(\mathrm{N}=113)$ 在插播商业广告的间隙报告了他们对比赛的反应。对 纵向数据的多级分析显示, 正面和负面的情感变化影响两队的支持者的悬念。同样, 不论球迷 偏爱哪一队, 情感倾向 (偏于一队 ) 成为更大的悬念的先决条件, 即使习惯性的球迷的承诺也 不影响悬念。利用对喜爱球队胜利较低的确定性和较小的比分差异而预测的不断增加的悬念只 是在赢队的支持者那里得到支持。 


\section{Sports Spectators' Suspense: Affect and Uncertainty in Sports Entertainment}

To explain the attraction to sports in the media, suspense theory is extended to predict suspense during sports exposure. Viewers $(\mathrm{n}=113)$ of a college football game in an intense rivalry context reported their responses to the game during commercial breaks. Multilevel analysis of the longitudinal data shows that shifts in both positive and negative affect influence suspense of supporters of both teams. Likewise, affective dispositions (rooting for a team) emerge as precondition for greater suspense, regardless of specific team preference, even though habitual fan commitment did not affect suspense. Predictions regarding increased suspense due to lower certainty of the favored team's victory and due to smaller score difference were only corroborated for supporters of the winning team.

Spannung bei Sportzuschauern: Affekt und Ungewissheit bei der Sportunterhaltung

Um die Anziehungskraft von Sport in den Medien zu erklären, wurde die Suspense-Theorie erweitert, um Suspense bei der Rezeption von Sport zu erklären. Die Zuschauer $(n=113)$ von College-Football- Spielen mit großem Konkurrenzkampf gaben Auskunft während der Werbepausen. Eine Mehrebenenanalyse der Langzeitdaten zeigt, dass Veränderungen des positiven und negativen Affekts die Suspense der Anhänger beider Teams beeinflusste. Affektive Dispositionen (Anfeuern eines Teams) zeigt sich als Vorbedingung für größere Suspense unabhängig von der Präferenz für ein bestimmtes Team. Gewohnheitsmäßige Anhängerschaft beeinflusste Suspense nicht. Annahmen bezüglich einer gesteigerter Suspense aufgrund der niedrigeren Wahrscheinlichkeit eines Sieges des favorisierten Teams und geringerer Punktunterschiede wurden nur für die Unterstützer des Gewinnerteams nachgewiesen. 


\section{Sports Spectators' Suspense: Affect}

\section{and Uncertainty in Sports Entertainment}

\section{스포츠 관람자들의 서스펜스:}

\section{스포츠 오락에서의 영항과 불확실성}

Silvia Knobloch-Westerwick1, Prabu David1, Matt Eastin2,

Ronald Tamborini3, \& Dara Greenwood4

1 School of Communication, Ohio State University, Columbus, OH 43210, USA

2 University of Texas

3 Michigan State University

4 University of Michigan

요약

미디어에서 스포츠에 대한 매력을 설명하기 위하여, 서스펜스 이론이 스포츠관람

동안의 서스펜스를 예측하기 위하여 확대되었다. 강도높은 라이벌 상황에서의 대

학미식축구를 관람한 113 명에게 상업광고방송시간중 게임에 대한 그들의 반응을

보고하게 하였다. 종단면 자료의 다면적분석은 긍정적 그리고 부정적 영향 모두 양

쪽팀의 지지자들의 서스펜스에 영향을 주는것에 있어 변화가 있었다는 것을 보여

주고 있다. 마찬가지로, 감정적인 경향이 특정한 팀에 대한 선호도와 관계없이 더욱

큰 정도의 서스펜스에 대한 사전조건으로 출현하였다. 자신이 선호하는 팀의 승리 
에 대한 낮은 정도의 확 실성때문에, 그리고 작은 정도의 점수 차 이때문에 나타나는 증가된 서스펜스에 대한 예측들은 승리팀의 지지자들에 대해서만 확실하게 나타 났다. 


\title{
El Suspenso de los Espectadores de Deportes: El Afecto y la Inseguridad en el Entretenimiento de los Deportes \\ Silvia Knobloch-Westerwick1, Prabu David1, Matt Eastin2, Ronald Tamborini3, \& Dara Greenwood4
}

\begin{abstract}
Resumen
Para explicar la atracción a los deportes en los medios, la teoría de suspenso es extendida para predecir el suspenso durante la exposición a los deportes. Los espectadores de juego de fútbol de una universidad $(n=113)$ en un contexto de rivalidad reportaron sus respuestas al juego durante los cortes comerciales. Un análisis multinivel de datos longitudinales muestra que los cambios positivos y negativos del afecto influenciaron el suspenso de los hinchas de ambos equipos. Asimismo, las disposiciones afectivas (arraigadas en el equipo) emergieron como precondición para el mayor suspenso, a pesar de la preferencia por el equipo, aún cuando el compromiso habitual de los fans no afectó el suspenso. Las predicciones acerca del incremento del suspenso debido a la baja inseguridad de la Victoria del grupo favorito y debido a la diferencia menor en el resultado fueron corroborados solamente por los hinchas del equipo ganador.
\end{abstract}

